\title{
Puffy hands and periosteal hyperostosis from inhalant abuse
}

\author{
Chen Xie $\bullet$, ${ }^{1,2}$ Meika Fang ${ }^{1}$
}

${ }^{1}$ Department of Medicine, Rheumatology Section, VA Greater Los Angeles Healthcare System, Los Angeles, California, USA

${ }^{2}$ Department of Medicine, Division of Rheumatology, UCLA, Los Angeles, California, USA

\section{Correspondence to}

Dr Chen Xie;

chenxie@mednet.ucla.edu

Accepted 20 January 2020

\section{DESCRIPTION}

A 37-year-old man presented to his primary care physician with several weeks of diffusely puffy hands (figure 1). Two months previously, he had

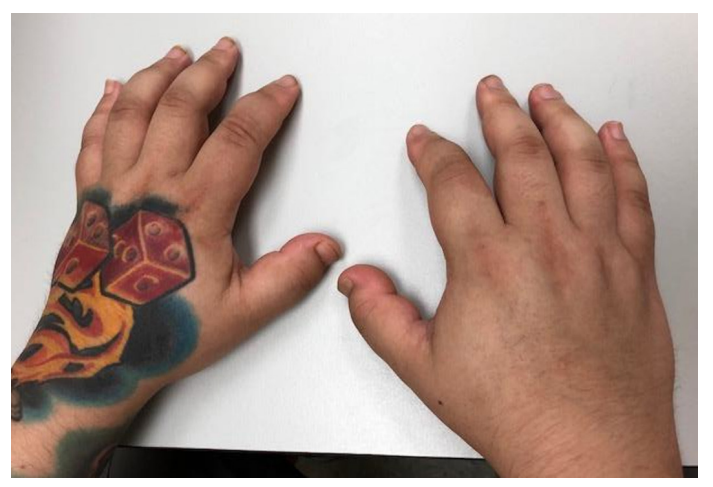

Figure 1 Diffuse swelling of bilateral hands and fingers, especially at the proximal and middle phalanges.
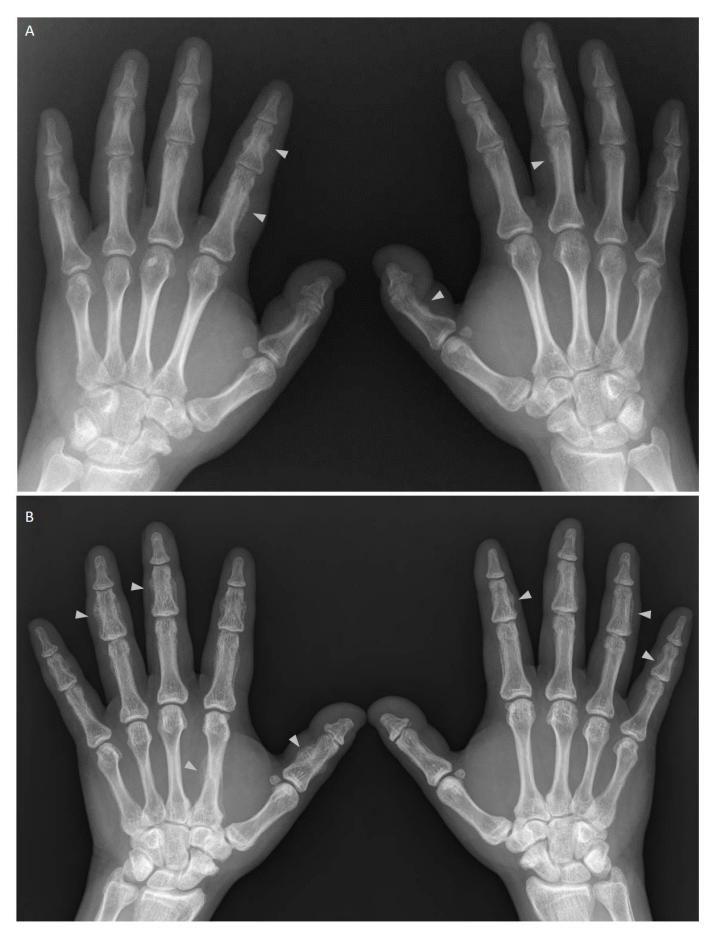

Figure 2 (A) Anteroposterior radiograph of the bilateral hands shows fluffy periosteal new bone formation (indicated by arrowheads) at scattered proximal and middle phalanges. (B) Repeat radiograph 14 months later shows progression of periosteal new bone formation (indicated by arrowheads) in the phalanges and metacarpal bones in the setting of ongoing compressed gas duster abuse. visited the emergency department for a minor burn to the right hand; he had a normal radiograph of the right hand and no swelling noted on examination at that time. At the present visit, he had tenderness over his middle and distal phalanges with no digital clubbing, joint swelling, skin thickening or rashes. He had no recent infections or hand trauma and had not started any new medications. Hand radiographs showed periosteal new bone formation at several phalanges (figure 2A). Laboratory testing was notable for alkaline phosphatase of $597 \mathrm{U} / \mathrm{L}$ (normal $<94$ ) with a bone fraction of $84 \%$. His thyroidstimulating hormone was 2.29 (normal 0.554.78 ) and his chest radiograph showed evidence of pulmonary venous congestion with no nodules or masses. He revealed that he had been inhaling up to 10 cans of compressed gas duster daily for 3 months. Subsequently, a serum fluoride level was obtained and found to be $1.6 \mathrm{mg} / \mathrm{L}$ (normal $<0.13$ ), supporting a diagnosis of skeletal fluorosis from inhalation of compressed gas duster containing 1,1-difluoroethane. He continued to abuse up to 24 cans of duster daily over the next year. Repeat hand radiographs 14 months later showed progression of periosteal new bone formation at the phalanges and metacarpal bones (figure 2B).

Skeletal fluorosis is a metabolic bone disease caused by excess fluoride intake. Swollen hands with underlying symmetric periosteal hyperostosis are a common manifestation of this condition and can develop rapidly, as this report demonstrates. ${ }^{1}$

\section{Learning points}

- Compressed gas duster contains fluoride; its abuse is an increasingly recognised cause of fluoride toxicity.

- Consider skeletal fluorosis on the differential diagnosis when symmetric periosteal hyperostosis is seen in the hands.

- The additional finding of digital clubbing is inconsistent with skeletal fluorosis and should prompt consideration of thyroid acropachy or hypertrophic osteoarthropathy.

\section{Patient's perspective}

It was a frightening and dangerous experience. My hands were hurting and I couldn't make a fist. I hope this can help someone in the future. 
However, digital clubbing is not seen with skeletal fluorosis and its presence is more consistent with hypertrophic osteoarthropathy or thyroid acropachy. Other musculoskeletal manifestations of skeletal fluorosis include tubular bone and axial skeleton osteosclerosis, joint ankylosis and ligament calcification. Fluoride stimulates formation of bone that lacks normal structure and strength through several possible mechanisms including alteration of bone crystal structure, delaying of bone mineralisation and conversion of hydroxyapatite to fluorapatite which is more resistant to acid dissolution. ${ }^{2}$

Compressed gas dusters are used to clean electronic equipment and commonly contain fluorocarbon compounds for ease of compressibility. Abuse of these dusters is an increasingly recognised cause of skeletal fluorosis. ${ }^{34}$ Other causes include consumption of well water containing high levels of fluoride, exposure to industrial processes such as coal burning, chronic use of medications containing a fluoride moiety such as voriconazole and excess ingestion of fluoride-containing tea or toothpaste. ${ }^{4}$ The clinical and radiographic manifestations of skeletal fluorosis may be slowly reversible over years to decades after cessation of fluoride intake. ${ }^{5}$ This patient eventually sought inpatient treatment and has abstained from further inhalant abuse for several months.
Acknowledgements We would like to thank Dr Daniel Garcia for initially bringing this case to our attention.

Contributors $C X$ and MF formulated the idea of the article, performed the literature search, wrote the article and managed the case. MF identified the case and is the guarantor. The patient reviewed the article and contributed a comment on his perspective of the case.

Funding The authors have not declared a specific grant for this research from any funding agency in the public, commercial or not-for-profit sectors.

Competing interests None declared.

Patient consent for publication Obtained.

Provenance and peer review Not commissioned; externally peer reviewed.

\section{ORCID iD}

Chen Xie http://orcid.org/0000-0003-4738-2117

\section{REFERENCES}

1 Soriano M, Manchón F. Radiological aspects of a new type of bone fluorosis, periostitis deformans. Radiology 1966;87:1089-94.

2 Everett ET. Fluoride's Effects on the Formation of Teeth and Bones, and the Influence of Genetics. J Dent Res 2011;90:552-60.

3 Cohen E, Hsu RY, Evangelista P, et al. Rapid-Onset diffuse skeletal fluorosis from inhalant abuse. JBJS Case Connect 2014;4:e108.

4 Tucci JR, Whitford GM, McAlister WH, et al. Skeletal fluorosis due to inhalation abuse of a difluoroethane-containing computer cleaner. J Bone Miner Res 2017;32:188-95.

5 Kurland ES, Schulman RC, Zerwekh JE, et al. Recovery from skeletal fluorosis (an enigmatic, American case). J Bone Miner Res 2007;22:163-70.

Copyright 2020 BMJ Publishing Group. All rights reserved. For permission to reuse any of this content visit

https://www.bmj.com/company/products-services/rights-and-licensing/permissions/

BMJ Case Report Fellows may re-use this article for personal use and teaching without any further permission.

Become a Fellow of BMJ Case Reports today and you can:

- Submit as many cases as you like

- Enjoy fast sympathetic peer review and rapid publication of accepted articles

- Access all the published articles

Re-use any of the published material for personal use and teaching without further permission

Customer Service

If you have any further queries about your subscription, please contact our customer services team on +44 (0) 2071111105 or via email at support@bmj.com.

Visit casereports.bmj.com for more articles like this and to become a Fellow 